\title{
Nocardiopsis arabia sp. nov., a halotolerant actinomycete isolated from a sand-dune soil
}

Correspondence

Wael N. Hozzein

hozzein29@yahoo.com

\author{
Wael N. Hozzein ${ }^{1}$ and Michael Goodfellow ${ }^{2}$ \\ ${ }^{1}$ Botany Department, Faculty of Science, Beni-Suef University, Beni-Suef, Egypt \\ ${ }^{2}$ Division of Biology, University of Newcastle, Newcastle upon Tyne NE1 7RU, UK
}

\begin{abstract}
The taxonomic status of an unknown actinomycete isolated from a sand-dune soil was established using a polyphasic approach. Isolate $S 186^{\top}$ had chemotaxonomic and morphological properties consistent with its classification in the genus Nocardiopsis, grew on agar plates at $\mathrm{NaCl}$ concentrations of up to $15 \%(\mathrm{w} / \mathrm{v})$ and formed a distinct phyletic line in the Nocardiopsis $16 \mathrm{~S}$ rRNA gene sequence tree. Its closest phylogenetic neighbours were Nocardiopsis chromatogenes, Nocardiopsis composta, Nocardiopsis gilva and Nocardiopsis trehalosi, with sequence similarity to the various type strains of $96.9 \%$, but it was readily distinguished from the type strains of these and related species using a range of phenotypic properties. It is apparent from the genotypic and phenotypic data that strain $S 186^{\top}$ belongs to a novel species of the genus Nocardiopsis, for which the name Nocardiopsis arabia sp. nov. is proposed. The type strain is S186 ${ }^{\top}$ (=CGMCC $4.2057^{\top}=$ DSM $\left.45083^{\top}\right)$.
\end{abstract}

The genus Nocardiopsis was proposed by Meyer (1976) on the basis of chemotaxonomic and morphological characteristics. At the time of writing, the taxon encompasses 24 recognized species (Li et al., 2006), which form a distinct clade within the evolutionary radiation occupied by members of the family Nocardiopsaceae (Rainey et al., 1996; Cui et al., 2001; Kroppenstedt \& Evtushenko, 2006). Nocardiopsis strains are frequently isolated from saline and alkaline soils (Li et al., 2004, 2006; Hozzein et al., 2004), but have also been recovered from an alkaline slag dump (Schippers et al., 2002), clinical material (Yassin et al., 1997; Mordarska et al., 1998), indoor environments (Peltola et al., 2001), the atmosphere of a composting facility (Kämpfer et al., 2002) and a marine sediment (Sabry et al., 2004). In the present polyphasic study, an actinomycete isolated from a sand-dune soil was shown to represent a novel species of the genus Nocardiopsis.

Strain $\mathrm{S} 186^{\mathrm{T}}$ was isolated on an M1 agar plate (Mincer et al., 2002) that had been inoculated with a suspension of a sand-dune soil (with a $\mathrm{pH}$ of 7.8), collected from Borg Al-Arab, Egypt, and incubated at $28{ }^{\circ} \mathrm{C}$ for 14 days. The isolate was maintained on modified Bennett's (Jones, 1949) and yeast extract-malt extract (ISP medium 2; Shirling \& Gottlieb, 1966) agars at room temperature and as glycerol suspensions of hyphae and spores $(20 \%, \mathrm{v} / \mathrm{v})$ at $-20{ }^{\circ} \mathrm{C}$. Biomass for chemotaxonomic and molecular systematic studies was derived from a 7-day-old modified Bennett's broth (Jones, 1949) shake culture incubated at $28{ }^{\circ} \mathrm{C}$,

The GenBank/EMBL/DDBJ accession number for the 16S rRNA gene sequence of strain $\mathrm{S} 186^{\top}$ is EF095149. harvested by centrifugation and washed twice with distilled water.

Extraction of chromosomal DNA, PCR amplification and direct sequencing of the 16S rRNA gene from isolate $S 186^{\mathrm{T}}$ were achieved using established procedures (Chun \& Goodfellow, 1995). The resultant sequence was aligned manually with the corresponding sequences of strains classified within the family Nocardiopsaceae, as retrieved from the GenBank/EMBL/DDBJ databases using the pairwise alignment option and 16S rRNA secondary structure information held within the PHYDIT program (available at http://plaza.snu.ac.kr/ jchun/phydit/). Phylogenetic trees were inferred using the least-squares (Fitch \& Margoliash, 1967), maximum-likelihood (Felsenstein, 1981), maximum-parsimony (Kluge \& Farris, 1969) and neighbour-joining (Saitou \& Nei, 1987) tree-making algorithms from the PHYLIP suite of programs (Felsenstein, 1993). Evolutionary distance matrices were generated for the least-squares and neighbour-joining methods as described by Jukes \& Cantor (1969) and the resultant unrooted tree topologies were evaluated in a bootstrap analysis (Felsenstein, 1985) of the neighbourjoining dataset (based on 1000 resamplings) using the CONSENSE and SEQBOOT options from the PHYLIP package. A comparison of the sequence of $S 186^{\mathrm{T}}$ with those of representatives of genera classified within the family Nocardiopsaceae showed that the isolate fell within the evolutionary radiation occupied by the genus Nocardiopsis (data not shown). The 16S rRNA gene sequence similarity between strain $\mathrm{S} 186^{\mathrm{T}}$ and the type strains of Nocardiopsis species ranged from 94.2 to $96.9 \%$. 
Chemosystematic studies were carried out to establish whether isolate $\mathrm{S} 186^{\mathrm{T}}$ had a chemical profile consistent with its assignment to the genus Nocardiopsis. Standard procedures were used to extract and analyse the isomeric forms of diaminopimelic acid (Staneck \& Roberts, 1974), the whole-organism sugars (Hasegawa et al., 1983), the muramic acid type (Uchida et al., 1999), the isoprenoid quinones (Minnikin et al., 1984; Collins, 1994), the polar lipids (Minnikin et al., 1984) and the fatty acids (Sutcliffe, 2000). The isolate was characterized by the following: the presence of meso-diaminopimelic acid, galactose and glucose in whole-organism hydrolysates (wall chemotype III, according to Lechevalier \& Lechevalier, 1970), Nacetylated muramic acid, tetrahydrogenated and hexahydrogenated menaquinones with 10 isoprene units as the predominant isoprenologues (menaquinone type 4C2; according to Kroppenstedt, 1985) and the presence of phosphatidylcholine, phosphatidylmethylethanolamine, diphosphatidylglycerol, phosphatidylglycerol, phosphatidylinositol, phosphatidylinositol mannosides, two uncharacterized glycolipids and two unknown phospholipids with high $R_{\mathrm{F}}$ values (above that of diphosphatidylglycerol) as major polar lipids (phospholipid type III, according to Lechevalier et al., 1977). The fatty acid profile was dominated by iso-/anteiso-branched and 10-methylbranched fatty acids. The principal components were 14methylpentadecanoic acid (iso- $\mathrm{C}_{16: 0}, 34 \%$ ), 10-methyloctadecanoic acid (tuberculostearic acid; 10-methyl $\mathrm{C}_{18: 0}$, $17.3 \%$ ) and 14-methylhexadecanoic acid (anteiso- $\mathrm{C}_{17: 0}$, $14.6 \%$ ), though smaller proportions of iso-heptadecanoic acid (iso- $\mathrm{C}_{17: 0}, 7.4 \%$ ), iso-octadecanoic acid (iso- $\mathrm{C}_{18: 0}$, $4.0 \%)$ and 10-methylheptadecanoic acid (10-methyl $\mathrm{C}_{17: 0}$, $4.8 \%$ ) were detected (fatty acid type $3 \mathrm{~d}$, according to Kroppenstedt, 1985). All of these chemical properties are consistent with the classification of the isolate in the genus Nocardiopsis (Grund \& Kroppenstedt, 1990; Kroppenstedt, 1992; Kroppenstedt \& Evtushenko, 2006).

It is apparent from Fig. 1 that isolate $\mathrm{S} 186^{\mathrm{T}}$ forms a distinct phyletic line towards the periphery of the Nocardiopsis gene tree, being more closely related to Nocardiopsis chromatogenes KCTC $19008^{\mathrm{T}}$, Nocardiopsis composta DSM $44551^{\mathrm{T}}$, Nocardiopsis gilva KCTC $19006^{\mathrm{T}}$ and Nocardiopsis trehalosi VKM Ac- $942^{\mathrm{T}}$ (with similarity of $96.9 \%$ ) than to Nocardiopsis halophila DSM $44494^{\mathrm{T}}(96.8 \%)$ and $N$. baichengensis KCTC $19009^{\mathrm{T}}$ (96.7\%). DNA-DNA relatedness experiments were not carried out between isolate $\mathrm{S} 186^{\mathrm{T}}$ and its closest phylogenetic neighbours, as the type strains of most of the latter share higher 16S rRNA gene sequence similarities, but have levels of DNA-DNA relatedness well below the $70 \%$ cut-off point recommended for the assignment of strains to the same genomic species (Wayne et al., 1987). The type strains of $N$. baichengensis and $N$. halophila, for example, share a $16 \mathrm{~S}$ rRNA gene sequence similarity of $99.9 \%$ but have a DNA-DNA relatedness value of only $55.9 \%$ (Li et al., 2006). Similarly, the type strain of $N$. composta shares $16 \mathrm{~S}$ rRNA gene sequence similarity of 97.5 and $97.4 \%$ with the type strains of $N$. halophila and $N$.

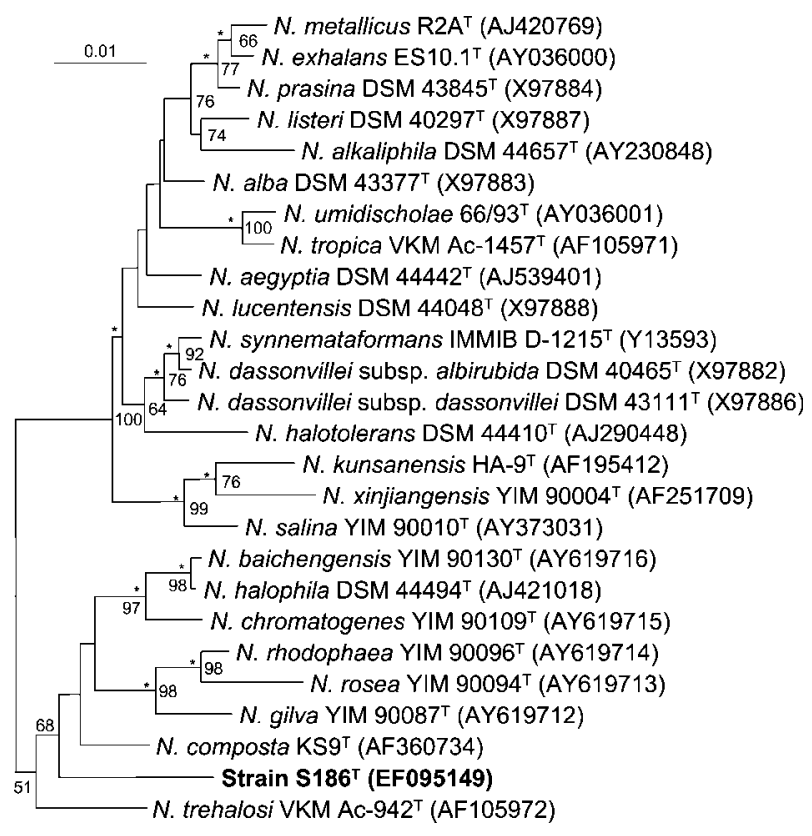

Fig. 1. Neighbour-joining phylogenetic tree, based on 16S rRNA gene sequences, showing the position of isolate $S 186^{\top}$ within the Nocardiopsis gene tree. Asterisks indicate branches of the tree that were also recovered using the least-squares, maximumlikelihood and maximum-parsimony tree-making algorithms. Numbers at nodes are bootstrap percentages (based on 1000 resampled datasets); only values above $50 \%$ are given. The sequence of Actinomadura madurae DSM $43067^{\top}$ (GenBank accession no. X97889) was used as an outgroup (not shown). Bar, 0.01 substitutions per nucleotide position.

chromatogenes, respectively, but shows DNA-DNA relatedness of $0 \%$ with respect to these strains (Li et al., 2006).

The cultural properties of the isolate, notably the aerial spore-mass colour, the pigmentation of the substrate mycelium and the colour of any diffusible pigments, were recorded on tryptone-yeast extract, yeast extract-malt extract, oatmeal, inorganic salts-starch and glycerolasparagine agars (ISP media 1 to 5, respectively; Shirling \& Gottlieb, 1966) after 2 weeks at $28{ }^{\circ} \mathrm{C}$; colours were recorded using the National Bureau of Standards Color Name Charts (Kelly, 1958; National Bureau of Standards, 1964). The arrangement of undisturbed hyphae, notably aerial hyphae and spore chains, was observed on modified Bennett's agar (Jones, 1949) after 15 days at $28{ }^{\circ} \mathrm{C}$, using the cover-slip technique of Kawato \& Shinobu (1959). Growth on the cover-slips was fixed and examined as described by Zhou et al. (1998). Additional morphological properties were determined by examining a gold-coated dehydrated preparation with a Cambridge Stereoscan 240 scanning electron microscope, using the procedure described by O'Donnell et al. (1993).

The strain grew well on all of the ISP media, producing a pale-yellow to deep greyish-yellow substrate mycelium that 
Table 1. Phenotypic characteristics that serve to differentiate strain $S 186^{\top}$ and representatives of closely related Nocardiopsis species

Strains: 1 , S186 ${ }^{\mathrm{T}} ; 2$, N. baichengensis KCTC $19009^{\mathrm{T}} ; 3$, N. chromatogenes KCTC $19008^{\mathrm{T}} ; 4$, N. composta DSM 44551 ${ }^{\mathrm{T}} ; 5$, N. gilva KCTC $19006^{\mathrm{T}} ; 6$, N. halophila DSM 44494 $;$ 7, N. rhodophaea KCTC $19049^{\mathrm{T}} ; 8$, N. rosea KCTC $19007^{\mathrm{T}}$; 9, N. trehalosi VKM Ac-942 ${ }^{\mathrm{T}}$. Data for reference type strains were taken from Al-Tai \& Ruan (1994), Evtushenko et al. (2000), Kämpfer et al. (2002) and Li et al. (2006). +, Positive; -, negative; w, weak; ND, not determined/no data available.

\begin{tabular}{|c|c|c|c|c|c|c|c|c|c|}
\hline Characteristic & 1 & 2 & 3 & 4 & 5 & 6 & 7 & 8 & 9 \\
\hline Spore chains & Long & Long & Long & Long & Short & Long & Short & Short & Long \\
\hline \multicolumn{10}{|c|}{ Growth on ISP 5 medium* ${ }^{*}$} \\
\hline Aerial mycelium & $\mathrm{YW}$ & wH & wH & wH & PY & WH & $\mathrm{PP}$ & PP & wH \\
\hline Soluble pigments & None & None & YP & None & None & ND & None & None & ND \\
\hline \multicolumn{10}{|c|}{ Growth on sole carbon sources } \\
\hline Cellobiose & + & + & + & $\mathrm{ND}$ & + & $\mathrm{ND}$ & - & - & ND \\
\hline D-Fructose & + & + & + & + & + & + & - & + & + \\
\hline Maltose & + & + & + & - & - & + & - & + & + \\
\hline D-Mannitol & + & + & + & $\mathrm{ND}$ & + & + & - & - & + \\
\hline D-Mannose & + & + & + & + & - & + & - & - & + \\
\hline Raffinose & - & - & + & $\mathrm{ND}$ & + & + & - & - & $\mathrm{ND}$ \\
\hline D-Ribose & - & + & + & + & - & + & + & + & - \\
\hline D-Sorbitol & + & - & - & $\mathrm{ND}$ & + & $\mathrm{ND}$ & - & - & - \\
\hline Sucrose & + & + & + & - & + & + & - & + & - \\
\hline D-Xylose & - & - & + & - & + & + & - & - & + \\
\hline \multicolumn{10}{|c|}{ Temperature for growth $\left({ }^{\circ} \mathrm{C}\right)$} \\
\hline Optimum & $28-30$ & $37-40$ & $37-40$ & 37 & $28-30$ & 30 & $37-40$ & $37-40$ & $28-37$ \\
\hline \multicolumn{10}{|c|}{$\mathrm{NaCl}$ concentration for growth (\%) } \\
\hline Range & $0-15$ & $0-18$ & $0-18$ & $0-10$ & $0-18$ & $3-20$ & $0-18$ & $0-18$ & $0-5$ \\
\hline Optimum & 5 & $5-8$ & $5-8$ & $5-10$ & $5-8$ & $5-15$ & $5-8$ & $5-8$ & $0-5$ \\
\hline Major menaquinones & $\begin{array}{r}10\left(\mathrm{H}_{4}\right) \\
10\left(\mathrm{H}_{6}\right)\end{array}$ & $\begin{array}{l}9\left(\mathrm{H}_{4}\right), 10\left(\mathrm{H}_{2}\right), \\
10\left(\mathrm{H}_{4}\right), 10\left(\mathrm{H}_{6}\right)\end{array}$ & $\begin{array}{c}10,10\left(\mathrm{H}_{2}\right), \\
10\left(\mathrm{H}_{4}\right)\end{array}$ & $\begin{array}{c}10\left(\mathrm{H}_{8}\right), 11\left(\mathrm{H}_{8}\right) \\
10\left(\mathrm{H}_{6}\right), 12\end{array}$ & $\begin{array}{c}11\left(\mathrm{H}_{4}\right), 11\left(\mathrm{H}_{6}\right), \\
11\left(\mathrm{H}_{8}\right)\end{array}$ & $10\left(\mathrm{H}_{6}\right), 10\left(\mathrm{H}_{8}\right)$ & $\begin{array}{r}11\left(\mathrm{H}_{6}\right) \\
11\left(\mathrm{H}_{8}\right)\end{array}$ & $\begin{array}{c}11,11\left(\mathrm{H}_{2}\right), \\
11\left(\mathrm{H}_{4}\right)\end{array}$ & $10\left(\mathrm{H}_{4}\right), 10\left(\mathrm{H}_{6}\right)$ \\
\hline
\end{tabular}

${ }^{*}{ }_{\mathrm{GY}}$, Greyish yellow; MB, moderately brown; OY, orange-yellow; PP, pale pink; PY, pale yellow; RB, reddish brown; RP, reddish pink; SB, soft brown; wH, white; YB, yellow-brown; YP, yellowish pink; YW, yellowish white. 
carried white aerial hyphae; diffusible pigments were not produced. Well-developed, branched substrate hyphae that fragmented into coccoid and rod-shaped elements were produced. Long, straight spore chains (with 10-20 spores per chain) were borne on aerial hyphae. The spores were rod-shaped, of variable length $(0.7-1.5 \mu \mathrm{m})$ and had smooth surfaces.

Isolate $\mathrm{S} 186^{\mathrm{T}}$ was examined for a range of phenotypic markers, using standard procedures (Gordon \& Mihm, 1962; Williams et al., 1983). Gram and Ziehl-Neelsen's stains were applied to cells grown on modified Bennett's agar (Jones, 1949) for 7 days at $28{ }^{\circ} \mathrm{C}$. The hanging drop method was used to test for motility. The results are given in Table 1 and in the species description. It is evident from Table 1 that strain $S 186^{\mathrm{T}}$ can be distinguished from the type strains of its closest phylogenetic neighbours using a combination of phenotypic features.

It can be concluded from the genotypic and phenotypic data that isolate $S 186^{\mathrm{T}}$ is phylogenetically distant from its neighbours and distinguishable from them on the basis of its phenotypic properties. Therefore $\mathrm{S} 186^{\mathrm{T}}$ represents a novel species of the genus Nocardiopsis, for which the name Nocardiopsis arabia sp. nov. is proposed.

\section{Description of Nocardiopsis arabia sp. nov.}

Nocardiopsis arabia (a.ra'bi.a. L. fem. adj. arabia pertaining to Arabia, referring to the isolation of the type strain in Egypt).

Aerobic, Gram-positive, non-acid-alcohol-fast, non-motile actinomycete. Forms a branched substrate mycelium that fragments into coccoid and rod-shaped elements. Aerial hyphae differentiate into straight to flexuous chains of rodshaped spores $(0.7-1.5 \mu \mathrm{m})$ with smooth surfaces. Paleyellow to deep greyish-yellow substrate mycelium that carries white aerial hyphae is formed on ISP media 1-5. Diffusible pigments are not produced. Grows between 10 and $40{ }^{\circ} \mathrm{C}$ (optimally around $28{ }^{\circ} \mathrm{C}$ ). Hydrolyses aesculin but not arbutin. Degrades casein and hypoxanthine, but not adenine, guanine, tyrosine, uric acid or xanthine. DArabinose, meso-erythritol, D-salicin and trehalose (all at $1 \%, \mathrm{w} / \mathrm{v}$ ) are used as sole carbon sources for energy and growth, but L-arabitol, melezitose and xylitol (all at $0.1 \%$, $\mathrm{w} / \mathrm{v}$ ) are not. Similarly, sodium pyruvate and sodium succinate (all at $0.1 \%, \mathrm{w} / \mathrm{v}$ ) are used as sole carbon sources, but sodium malonate (at $0.1 \%, \mathrm{w} / \mathrm{v}$ ) is not. Growth occurs in the presence of $\mathrm{NaCl}$ at $0-15 \%, \mathrm{w} / \mathrm{v}$ (optimally around $5 \%)$. Additional phenotypic properties are shown in Table 1. Whole-organism hydrolysates contain meso-diaminopimelic acid and the sugars galactose and glucose. The major polar lipids are diphosphatidylglycerol, phosphatidylcholine, phosphatidylglycerol, phosphatidylinositol, phosphatidylinositol mannosides, phosphatidylmethylethanolamine, two unknown glycolipids and two unknown phospholipids with high $R_{\mathrm{F}}$ values (above that of diphosphatidylglycerol). The major menaquinones are MK-10 $\left(\mathrm{H}_{4}\right)$ and MK-10 $\left(\mathrm{H}_{6}\right)$; minor amounts of MK-11( $\left.\mathrm{H}_{6}\right)$ and
MK-9 $\left(\mathrm{H}_{4}\right)$ are present. The major fatty acids are iso$\mathrm{C}_{16: 0}$, tuberculostearic acid (10-methyl $\left.\mathrm{C}_{18: 0}\right)$ and anteiso$\mathrm{C}_{17: 0}$; iso- $\mathrm{C}_{17: 0}$, iso- $\mathrm{C}_{18: 0}$ and 10-methyl $\mathrm{C}_{17: 0}$ are present as minor fatty acids.

The type (and only) strain, S186 ${ }^{\mathrm{T}}$ (=CGMCC $4.2057^{\mathrm{T}}$ $\left.=\mathrm{DSM} 45083^{\mathrm{T}}\right)$, was isolated from a sand-dune soil collected at Borg El-Arab, Egypt.

\section{References}

Al-Tai, A. M. \& Ruan, J. S. (1994). Nocardiopsis halophila sp. nov., a new halophilic actinomycete isolated from soil. Int J Syst Bacteriol 44, 474-478.

Chun, J. \& Goodfellow, M. (1995). A phylogenetic analysis of the genus Nocardia with 16S rRNA gene sequences. Int J Syst Bacteriol 45, 240-245.

Collins, M. D. (1994). Isoprenoid quinones. In Chemical Methods in Prokaryotic Systematics, pp. 265-309. Edited by M. Goodfellow \& A. G. O’Donnell. Chichester: Wiley.

Cui, X.-L., Mao, P. H., Zeng, M., Li, W. J., Zhang, L. P., Xu, L. H. \& Jiang, C.-L. (2001). Streptomonospora salina gen. nov., sp. nov., a new member of the family Nocardiopsaceae. Int J Syst Evol Microbiol 51, 357-363.

Evtushenko, L. I., Taran, V. V., Akimov, V. N., Kroppenstedt, R. M., Tiedje, J. M. \& Stackebrandt, E. (2000). Nocardiopsis tropica sp. nov., Nocardiopsis trehalosi sp. nov., nom. rev. and Nocardiopsis dassonvillei subsp. albirubida subsp. nov., comb. nov. Int J Syst Evol Microbiol 50, 73-81.

Felsenstein, J. (1981). Evolutionary trees from DNA sequences: a maximum likelihood approach. J Mol Evol 17, 368-376.

Felsenstein, J. (1985). Confidence limits on phylogenies: an approach using the bootstrap. Evolution 39, 783-791.

Felsenstein, J. (1993). PHYLIP (phylogeny inference package), version 3.5.1. Distributed by the author. Department of Genome Sciences, University of Washington, Seattle, USA. http://evolution.gs.washington. edu/phylip.html

Fitch, W. M. \& Margoliash, E. (1967). Construction of phylogenetic trees: a method based on mutation distances as estimated from cytochrome $c$ sequences is of general applicability. Science 155, 279-284.

Gordon, R. E. \& Mihm, J. M. (1962). Identification of Nocardia caviae (Erikson) nov. comb. Ann N Y Acad Sci 98, 628-636.

Grund, E. \& Kroppenstedt, R. M. (1990). Chemotaxonomy and numerical taxonomy of the genus Nocardiopsis Meyer 1976. Int J Syst Bacteriol 40, 5-11.

Hasegawa, T., Takizawa, M. \& Tanida, S. (1983). A rapid analysis for chemical grouping of aerobic actinomycetes. J Gen Appl Microbiol 29, 319-322.

Hozzein, W. N., Li, W.-J., Ali, M. I. A., Hammouda, O., Mousa, A. S., Xu, L.-H. \& Jiang, C.-L. (2004). Nocardiopsis alkaliphila sp. nov., a novel alkaliphilic actinomycete isolated from desert soil in Egypt. Int J Syst Evol Microbiol 54, 247-252.

Jones, K. L. (1949). Fresh isolates of actinomycetes in which the presence of sporogenous aerial mycelia is a fluctuating characteristic. J Bacteriol 57, 141-145.

Jukes, T. H. \& Cantor, C. R. (1969). Evolution of protein molecules. In Mammalian Protein Metabolism, vol. 3, pp. 21-132. Edited by H. N. Munro. New York: Academic Press. 
Kämpfer, P., Busse, H. \& Rainey, F. A. (2002). Nocardiopsis compostus sp. nov., from the atmosphere of a composting facility. Int J Syst Evol Microbiol 52, 621-627.

Kawato, M. \& Shinobu, R. (1959). On Streptomyces herbaricolor sp. nov., supplement: a simple technique for microscopical observation. Mem Osaka Univ Lib Arts Educ B Nat Sci 8, 114-119.

Kelly, K. L. (1958). Centroid notations for the revised ISCC-NBS color name blocks. J Res Nat Bur Standards U S A 61, 427.

Kluge, A. G. \& Farris, F. S. (1969). Quantitative phyletics and the evolution of anurans. Syst Zool 18, 1-32.

Kroppenstedt, R. M. (1985). Fatty acid and menaquinone analysis of actinomycetes and related organisms. In Chemical Methods in Bacterial Systematics, pp. 173-199. Edited by M. Goodfellow \& D. E. Minnikin. London: Academic Press.

Kroppenstedt, R. M. (1992). The genus Nocardiopsis. In The Prokaryotes, 2nd edn, pp. 1139-1156. Edited by A. Balows, H. G. Trüper, M. Dworkin, W. Harder \& K.-H. Schleifer. New York: Springer.

Kroppenstedt, R. M. \& Evtushenko, L. I. (2006). The family Nocardiopsaceae. In The Prokaryotes: a Handbook on the Biology of Bacteria, 3rd edn, vol. 3, pp. 754-795. Edited by M. Dworkin, S. Falkow, E. Rosenberg, K. H. Schleifer \& E. Stackebrandt. New York: Springer.

Lechevalier, H. A. \& Lechevalier, M. P. (1970). A critical evaluation of the genera of aerobic actinomycetes. In The Actinomycetales, pp. 393405. Edited by H. Prauser. Jena: VEB Gustav Fischer.

Lechevalier, M. P., De Bièvre, C. \& Lechevalier, H. A. (1977). Chemotaxonomy of aerobic actinomycetes: phospholipid composition. Biochem Syst Ecol 5, 249-260.

Li, W.-J., Park, D.-J., Tang, S.-K., Wang, D., Lee, J.-C., Xu, L.-H., Kim, C.-J. \& Jiang, C.-L. (2004). Nocardiopsis salina sp. nov., a novel halophilic actinomycete isolated from saline soil in China. Int J Syst Evol Microbiol 54, 1805-1809.

Li, W. J., Kroppenstedt, R. M., Wang, D., Tang, S. K., Lee, J. C., Park, D. J., Kim, C. J., Xu, L. H. \& Jiang, C. L. (2006). Five novel species of the genus Nocardiopsis isolated from hypersaline soils and emended description of Nocardiopsis salina $\mathrm{Li}$ et al. 2004. Int J Syst Evol Microbiol 56, 1089-1096.

Meyer, J. (1976). Nocardiopsis, a new genus of the order Actinomycetales. Int J Syst Bacteriol 26, 487-493.

Mincer, T. J., Gensen, P. R., Kauffman, C. A. \& Fenical, W. (2002). Widespread and persistent populations of a major new marine actinomycete taxon in ocean sediments. Appl Environ Microbiol 68, 5005-5011.

Minnikin, D. E., O'Donnell, A. G., Goodfellow, M., Alderson, G., Athalye, M., Schaal, A. \& Parlett, J. H. (1984). An integrated procedure for the extraction of bacterial isoprenoid quinones and polar lipids. J Microbiol Methods 2, 233-241.

Mordarska, H., Zakrzewska-Czerwinska, J., Pasciak, M., Szponar, M. \& Rowinski, S. (1998). Rare suppurative pulmonary infection caused by Nocardiopsis dassonvillei recognized by glycolipid markers. FEMS Immunol Med Microbiol 21, 47-55.

National Bureau of Standards (1964). ISCC-NBS Color Manual Charts Illustrated with Centroid Colors. Supplement to NBS Circular 553. Washington, DC: US Government Printing Office.
O’Donnell, A. G., Falconer, C., Goodfellow, M., Ward, A. C. \& Williams, E. (1993). Biosystematics and diversity amongst novel carboxydotrophic actinomycetes. Antonie Van Leeuwenhoek 64, 325340.

Peltola, J. S. P., Andersson, M. A., Kämpfer, P., Auling, G., Kroppenstedt, R. M., Busse, H.-J., Salkinoja-Salonen, M. S. \& Rainey, F. A. (2001). Isolation of toxigenic Nocardiopsis strains from indoor environments and description of two new Nocardiopsis species, $N$. exhalans sp. nov. and N. umidischolae sp. nov. Appl Environ Microbiol 67, 4293-4304.

Rainey, F. A., Ward-Rainey, N., Kroppenstedt, R. M. \& Stackebrandt, E. (1996). The genus Nocardiopsis represents a phylogenetically coherent taxon and a distinct actinomycete lineage: proposal of Nocardiopsaceae fam. nov. Int J Syst Bacteriol 46, 1088-1092.

Sabry, S. A., Ghanem, N. B., Abu-Ella, G. A., Schumann, P., Stackebrandt, E. \& Kroppenstedt, R. M. (2004). Nocardiopsis aegyptia sp. nov., isolated from marine sediment. Int J Syst Evol Microbiol 54, 453-456.

Saitou, N. \& Nei, M. (1987). The neighbor-joining method: a new method for reconstructing phylogenetic trees. Mol Biol Evol 4, 406425.

Schippers, A., Bosecker, K., Willscher, S., Spröer, C., Schumann, P. \& Kroppenstedt, R. M. (2002). Nocardiopsis metallicus sp. nov., a metal-leaching actinomycete isolated from an alkaline slag dump. Int J Syst Evol Microbiol 52, 2291-2295.

Shirling, E. B. \& Gottlieb, D. (1966). Methods for characterization of Streptomyces species. Int J Syst Bacteriol 16, 313-340.

Staneck, J. L. \& Roberts, G. D. (1974). Simplified approach to identification of aerobic actinomycetes by thin-layer chromatography. Appl Microbiol 28, 226-231.

Sutcliffe, I. C. (2000). Characterisation of a lipomannan lipoglycan from the mycolic acid containing actinomycete Dietzia maris. Antonie Van Leeuwenhoek 78, 195-201.

Uchida, K., Kudo, T., Suzuki, K. \& Nakase, T. (1999). A new rapid method of glycolate test by diethyl ether extraction, which is applicable to a small amount of bacterial cells of less than one milligram. J Gen Appl Microbiol 45, 49-56.

Wayne, L. G., Brenner, D. J., Colwell, R. R., Grimont, P. A. D., Kandler, O., Krichevsky, M. I., Moore, L. H., Moore, W. E. C., Murray, R. G. E. \& other authors (1987). International Committee on Systematic Bacteriology. Report of the ad hoc committee on reconciliation of approaches to bacterial systematics. Int J Syst Bacteriol 37, 463-464.

Williams, S. T., Goodfellow, M., Alderson, G., Wellington, E. M. H., Sneath, P. H. A. \& Sackin, M. J. (1983). Numerical classification of Streptomyces and related genera. J Gen Microbiol 129, 1743-1813.

Yassin, A. F., Rainey, F. A., Burghardt, J., Gierth, D., Ungerechts, J., Lux, I., Seifert, P., Bal, C. \& Schaal, K. P. (1997). Description of Nocardiopsis synnemataformans sp. nov., elevation of Nocardiopsis alba subsp. prasina to Nocardiopsis prasina comb. nov., and designation of Nocardiopsis antarctica and Nocardiopsis alborubida as later subjective synonyms of Nocardiopsis dassonvillei. Int J Syst Bacteriol 47, 983-988.

Zhou, Z.-H., Liu, Z.-H., Qian, Y.-D., Kim, S. B. \& Goodfellow, M. (1998). Saccharopolyspora spinosporotrichia sp. nov., a novel actinomycete from soil. Int J Syst Bacteriol 48, 53-58. 